\title{
Serum Sclerostin Level in Relation to Bone Status in Children with Chronic Kidney Disease
}

\author{
AMIRA R. ABASS, M.Sc.*; ASHRAF A. ABDEL BASSET, M.D.*; AMANY K. EL-HAWARY, M.D.*; \\ MOHAMED M. ALI EL ASSMY, M.D.* and REHAM EL-FARAHATY, M.D.** \\ The Departments of Pediatrics* and Clinical Pathology**, Faculty of Medicine, Mansoura University and Minister of Health
}

\begin{abstract}
Background: To assess the serum level of sclerostin as a bone marker in children with different stages of Chronic Kidney Disease and its relation to bone status in children with CKD.

Aime of Study: Is to assess the serum level of sclerostin in children with different stages of CKD and its relation to bone status in those children.

Patients and Methods: The study was conducted on total of 90 children, 60 children of them were followed-up for diagnosis of CKD stages from II to V at Mansoura University Children Hospital (MUCH) Nephrology Unit. This study was done from March 2015 to March 2016. They were 34 (56.7\%) males and $26(43.3 \%)$ females with mean age SD of $11.06 \pm 3.4$ Control group of 30 healthy children and were 18 male $(60 \%)$ and $12(40 \%)$ female with mean age SD of $9.6 \pm 2.3$. Age ranges from three to seventeen years, complete blood picture, serum creatinine, parathyroid hormone, alkaline phosphatase, calcium, phosphorous and sclerostin serum level and also DEXA scan were measured in both groups. All patients were free from acute illness or symptoms suggestive of a urinary infection in the previous 3 months and none of them were receiving corticosteroids. Children with CKD who have diabetes, vascular calcifications or had undergone renal transplantation were excluded.
\end{abstract}

Results: Elevated serum sclerostin in CKD \& ESRD groups compared to control. Non-significant correlation between serum sclerostin level, biochemical bone markers and different anthropometeric measures.

Conclusions: Serum sclerostin was elevated in CKD \& ESRD suggesting as an indicator of bone mineral density in CKD patients but it is level didn't correlate as expected with observed BMD or bone turnover markers, suggesting presence of confounding variables that must be taken into account before routine clinical implementation. Non-significant correlation between serum sclerostin level and other biochemical bone markers as regard Calcium, phosphate, alkaline phosphatase and patathemone hormone. Non-significant correlation was also detected between sclerostin, bone mineral density and body composition.

Correspondence to: Dr. Amira R. Abass,

E-Mail: Amiraabbas 328@yahoo.com
Key Words: Chronic Kidney Disease (CKD) - End Stage Renal Disease (ESRD) - Bone Mineral Density (BMD).

\section{Introduction}

THE National Kidney Foundation-Kidney Disease Outcomes Quality Initiative, 2005 (NKF-K/DOQI) workgroup has defined CKD (Chronic Kidney Disease) presence of markers of kidney damage for 3 months structural, functional abnormalities of the kidney with or without decreased Glomerular Filtration Rate (GFR) including; abnormalities in the composition of blood or urine or abnormalities in imaging tests, or the presence of GFR $<60 \mathrm{~mL} /$ $\mathrm{min} / 1.73 \mathrm{~m}^{2} \geq 3$ months with or without other signs of kidney damage [1]

The Mineral and Bone Disorder (MBD) in CKD has been the first area of interest of the Kidney Disease Improving Global Outcomes foundation (KDIGO), which define CKD-MBD disease as due to either one or a combination of the following clinical situations: (A) Abnormalities of calcium, phosphorus, Parathyroid Hormone (PTH), or vitamin D metabolism; (B) Abnormalities in bone turnover, mineralization, volume, linear growth, or strength; (C) Vascular or other soft tissue calcification [2].

Changes in bone architecture can be caused by either a high bone turnover state or a low bone turnover state. Four types of bone phenotypes (renal osteodystrophy) can be diagnosed in CKD patients: Osteitis fibrosa cystica (high bone turnover with secondary hyperparathyroidism), osteomalacia (low bone turnover and inadequate mineralization, primarily related to diminished Vitamin D synthesis), adynamic bone disorder (low bone turnover from excessive suppression of the parathyroid glands) and mixed osteodystrophy (with elements 
of both high and low bone turnover). In pre-dialysis patients, high bone turnover bone disease is most prevalent; in contrast, low bone turnover predominates in dialysis patients. Patients with low turnover disease represent the majority of cases of renal osteodystrophy [3].

Bone turnover consists of an osteoclastic resorption phase followed by a phase of formation, which both occur in a defined time frame $(\sim 3$ months in healthy humans) and at a specific location at the bone surface. In dialysis patients, high PTH serum levels are not only associated with high bone turnover, but also with increased risk of allcause mortality, whereas low PTH levels are associated with low bone turnover, increase serum calcium and decreases phosphataemia by decreasing phosphate reabsorption in the proximal tubule [4].

Although PTH has important effects on bone turnover, it must be remembered that bone turnover is quite a slow process, which can take a few weeks in cases of high bone turnover, to a few months, or even years, whereas secretion of PTH is a very quick process (minutes) in response to variations in ionized calcium. Thus, an isolated measurement of serum PTH is unlikely to provide a valid representation of bone turnover, except in cases with extremely low or high value; specific b-ALP is released by osteoblasts and plays a major role in bone mineralization. Its serum concentration seems independent from glomerular filtration rate, thus, KDIGO recommendation is to measure phosphatase alkaline and especially b-ALP which can be considered as a true 'bone biomarker', the biological profile of b-ALP is better than PTH [5].

Pediatric reference values have been established for age-and gender independently for assessment of bone turnover in chronically diseased children by measurement of osteoclast activity by BAP, TRAP5b, sclerostin and c-terminal FGF-23 (cFGF23) and measurement of osteoblast activity by serum osteocalcin [6].

DEXA is one of the reference methods for the assessment of body composition in CKD patients, based on a three-compartmental model (total body minerals, lean mass and fat tissue mass). This is the most accurate way to measure BMD, it uses two different X-ray beams to estimate bone density in spine and hip. Strong, dense bones allow less of the X-ray beam to pass through them and the amounts of each X-ray beam that are blocked by bone and soft tissue are compared to each other. DEXA can measure as little as $2 \%$ of bone loss per year. It is fast and uses very low doses of radiation [7].

However, monitoring of CKD-MBD is challenging. Bone biopsy is considered the gold standard procedure in determining the clinical course and response to treatment. In stage 5 CKD, bone biopsy becomes the gold standard in the diagnosis of renal osteodystrophy. In contrast to stage 5 CKD, the role of bone biopsy in earlier stages of CKD, in particular stage 3 or 4 , is not well defined, but due to its invasiveness, currently recommended only in exceptional clinical situations. Hence serum Parathormone (PTH), calcium and phosphorus constitute the mainstay of CKD-MBD monitoring in routine clinical practice [7].

The peptide sclerostin is a novel key glycoprotein regulator of bone turnover and vascular calcification [8]. It is released mainly by osteocytes as a paracrine negative feedback signal regulating bone formation by inhibiting the differentiation of osteochondral precursor cells to osteoblasts [9].

The role of sclerostin remains unclear since it is a well-recognized as bone anti-anabolic protein and sclerostin antibody treatment improves bone formation and bone strength, but higher levels are associated with higher BMD and perhaps fewer fractures, at least in men but in patients with CKD, higher sclerostin levels are associated with decreased bone turnover [10] .

With regard to renal function, Cejka et al., [11], found that patients with Chronic Kidney Disease (CKD) stage 5 on dialysis had higher sclerostin levels than those without CKD and suggested elevated sclerostin may play a role in renal osteodystrophy. Also, recent report found that serum sclerostin levels increase as estimated Glomerular Filtration Rate (eGFR) decreases in patients with CKD [11].

\section{Patients and Methods}

This study was done on total 90 children, 60 children were followed-up for diagnosis of CKD stages from II to V at Mansoura University Children Hospital (MUCH) Nephrology Unit from March 2015 to March 2016. There were 34 (56.7\%) males and $26(43.3 \%)$ females with mean age \pm SD of $11.06 \pm$ 3.4. Control group comprised 30 healthy children and were 18 male $(60 \%)$ and $12(40 \%)$ female with mean age $\mathrm{SD} \pm$ was $9.6 \pm 2.3$.

All patients were free from acute illness or symptoms suggestive of a urinary infection in the previous 3 months and none of them were receiving 
cortico steroids. Children with CKD who have diabetes, vascular calcifications or had undergone renal transplantation were excluded. Age ranges from three to seventeen years.

\section{History and examination:}

Name, age, gender, address and phone numbers of each child were recorded. Each parent was asked about symptoms suggestive of renal impairment as increased or decreased frequency of urination, discolored urine, easy fatigability, vomiting, loss of appetite, headache, decreased mental sharpness, muscle twitches and cramps, swelling of feet and ankles, persistent itching and sleep disturbances.

All patients were examined for signs confirming renal failure such as disturbed conscious level, severe pallor, hypertension, puffy eye lids, edema lower limbs, tachycardia, galloping, tachypnea, crackling, diminished breath sounds, muscle cramps and convulsions.

\section{Biochemical parameters: \\ I- Creatinine clearance:}

Creatinine Clearance $(\mathrm{CrCl})$ was calculated for all children included in this study by Schwartz equation [12] as following:

$$
\mathrm{CrCl}\left(\mathrm{ml} / \mathrm{min} / 1.73 \mathrm{~m}^{2}\right)=\frac{[\text { Length }(\mathrm{cm}) \mathrm{X} \mathrm{k}]}{\text { Serum creatinine }}
$$

Where $k$ differs according to age and gender of children as following:

$\mathrm{k}=0.45$ for infants 1 to 52 weeks old.

$\mathrm{k}=0.55$ for children 1 to 13 years old .

$\mathrm{k}=0.55$ for adolescent females 13-18 years old.

$\mathrm{k}=0.7$ for adolescent males $13-18$ years old.

\section{Routine biochemical markers:}

Morning non fasting blood samples were withdrawn from all CKD (chronic kidney disease) participants. They were centrifuged to separate serum and stored at $-20^{\circ} \mathrm{C}$ until checked for monthly routine laboratory investigations. Serum concentrations of creatinine, albumin, calcium, phosphorus, alkaline phosphatase, Parathormone hormone (PTH) and ferritin were measured by Enzyme Linked Immunosorbent Assay (ELISA) in all patients.

Complete blood count and arterial blood gases were performed. Quantitative C-Reactive Protein (CRP) (quantitative turbidimetric assay) levels were used for determination of chronic inflammation.
Serum sclerostin level:

\section{Principal:}

Serum concentrations of sclerostin were measured by Enzyme Linked Immunosorbent Assay (ELISA). This ELISA kit uses the SandwichELISA. ELISA plate in this kit has been pre-coated with an antibody specific to Human SOST. Samples were added to the micro ELISA plate and combined with the specific antibody. Then a biotinylated and Avidin-Horseradish Peroxidase (HRP) conjugate detection antibody specific for Human SOST are added to each micro plate and wells incubated, free components are washed away. The substrate solution was added to each well, only those wells will appear blue in color as they contain Human SOST, biotinylated detection antibody and AvidinHRP conjugate. The enzyme-substrate reaction was terminated by the addition of stop solution and the color turns yellow. The Optical Density (OD) is measured by spectrophotomey with wavelength of $450 \mathrm{~nm} \pm 2 \mathrm{~nm}$ and its value was proportional to the concentration of Human SOST.

\section{Method:}

Add 100 sundard to each and well incubate for $90 \mathrm{~min}$ at $37 \mathrm{c}$, remove the liquid. Then add 100 Liotinylated Detection Ab, incubate for 1 hour at $37^{\circ} \mathrm{C}$, aspirate and wash 3 times. Followed by 100 HRP Conjugate, incubate for $30 \mathrm{~min}$ at $37 \mathrm{c}$, aspirate and wash 5 times, then add 90 substrate reagent, incubate for $15 \mathrm{~min}$ at $37 \mathrm{c}$, then add 50 sop solution and finally read at $450 \mathrm{~nm}$ then calculate the results.

\section{Recovery:}

The recovery of human SOST spiked at three different levels in samples throughout the range of the assay was evaluated in various matrices.

\section{Linearity:}

Samples were spiked with high concentrations of Human SOST and diluted with reference standard in order to produce samples with values within the range of the assay.

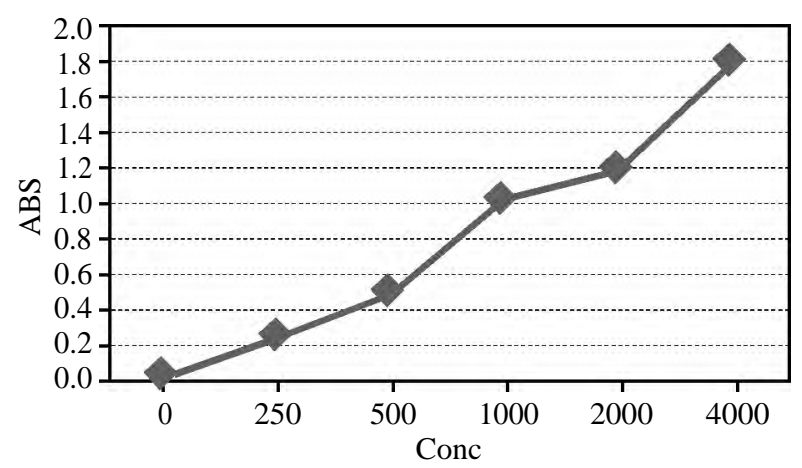

Fig. (1): Serum Sclerostin level (pg/ml). 


\section{Anthropometric evaluation:}

Anthropometric measures were obtained at the Mansoura University Children Hospital (MUCH) by trained interviewers with a standardized protocol and skill level. Anthropometric measures included weight, height, body mass index, their z-scores and percent body fat.

Salt and water imbalances were obstacles against accurate measurement of nutritional parameters of children with CRF and ESRD. Also, the potential inappropriateness of using age matched controls in a short population which may be delayed in puberty. Therefore, to allow perfect comparison with the normal healthy children, we used standarddeviation scores of weight, height and body mass index obtained according to Egyptian children and adolescents' reference data [13]

The Body Mass Index (BMI) was calculated by following formula:

$$
\mathrm{BMI}=\frac{\text { Weight }(\mathrm{kg})}{\text { Height }^{2}\left(\mathrm{~m}^{2}\right)}[\mathbf{1 4}]
$$

Percent body fat was obtained through Bioelectrical Impedance Analysis (BIA) technique, using body composition analyzer "Tanita BC-418 MA" (Tanita coop, Tokyo, Japan). All measurements were performed on the morning after overnight fasting (before dialysis of HD children and after voiding in the stages two to four CKD group and the control group.

\section{Plain left wrist $X$-ray:}

Each patient had plain X-ray on left wrist to help estimation of maturity of a child's skeletal system or what is called bone age. It is an indicator of physiological development that is expressed by pattern of ossification in the hand and wrist bones in a predictable manner till end of adolescence when the elongation of bone is complete.

\section{Method:}

Bone age X-rays were done by an X-ray technician in radiology department within $\mathrm{MUCH}$. It doesn't require special preparation except removing all clothing and jewelry from the area which was on the X-ray as they interfere with imaging. Child sited and placed his/ her left hand on the table with fingers spread. It is a safe and painless procedure that uses a small amount of radiation. Actual exposure is often less than few seconds.

\section{Calculation:}

Bone age of each child was calculated and level of maturation of hand and wrist bones was com- pared with normal bone age levels according to the Gilsanz \& Ratibi (GR) [15] Atlas that was developed by Vicente Gilsanz and Osman Ratibin. This atlas shows idealized artificial images specific for age and sex standards of skeletal maturity via analyzing the size, shape, morphology and density of ossification centers in left wrist plain X-ray of healthy children.

\section{Dual X-ray absorptiometry:}

Bone mineral density of total body and lumbar spine (L1-L4) was measured for each child using dual energy X-ray absorptiometry (DXA) (Lunar, DPXIQ-USA, software version 4.5). Densitometric data were reported where Bone Mineral Content (BMC) expressed in gram and Bone Mineral Density (BMD) expressed in $\mathrm{gm} / \mathrm{cm}^{2}$ according to following equation:

$$
\mathrm{BMD}=\frac{\mathrm{BMC}}{\text { Area }\left(\mathrm{g} / \mathrm{cm}^{2}\right)}[15]
$$

$\mathrm{Z}$-score was calculated and determined using Egyptian children and adolescents' reference data. Low BMD was considered if a Z-score of -2 or less obtained at any site.

\section{Principal:}

Lower energy beam or photon is attenuated by bone and soft tissue while higher energy source is affected only by bone (or metal), so it is easy to calculate the differential absorption and bone density is accurately assessed without impaction from surrounding soft tissue. This allows evaluation of thicker body bones involving complex geometry, such as the femoral neck and the spine.

\section{Method:}

Child's body acts as three-dimensional absorber and it is scanned by X-ray to produce twodimensional flat image on a photographic film. When the spine is scanned, the hips are flexed to flatten the normal lumbar lordosis. When femoral neck is scanned, the femur should be in slight internal rotation.

It is clinically important for early prediction of any bone abnormalities or fractures. It is preferable due to short scan times, easy set-up of patients for scanning, non-invasive technique, low radiation dose and good measurement precision. Scan time is only two to five minutes.

\section{Treatment received:}

All children with CKD and ESRD received calcium supplements, phosphate-binding medication, 1-25 $(\mathrm{OH}) 2$ vitamin $\mathrm{D}$, iron (oral or intrave- 
nous), erythropoietin, folic acid, vitamin B complex and antihypertensive drugs when necessary. Children with ESRD were maintained on 3-4 hemodialysis sessions weekly (4 hours/session). The children had normal acid-base balance (mean serum bicarbonate $=$ For ESRD group and for CRF group).

\section{Statistical analysis:}

Data entry and statistical analysis were performed using SPSS (statistical package of social sciences) version 16.0 (SPSS Inc., Chicago, IL, USA). Parametric data were expressed in mean \pm standard deviation. Non normal data were expressed in median, minimum and maximum. Normality of data was first tested by one sample K-S test. In addition, independent $t$ test was used to compare means for continous variables of each two different groups. Also, Mann-Whitney U test (z) was used to compare none normally distributed continuous variables in two different groups. In addition, one way anova test was used to compare means for continuous variables in three different groups. Then, each two different groups were compared by post hoc test (LSD). Pearson Chi-square tests were used to compare the categorical variables between the both cases and control groups. Strength of relationship between variables was tested by spearman's rank correlation coefficient. $p$-value $<0.05$ was considered as statistically significant.

\section{Results}

This study was done on total 90 children, 60 children were followed-up for diagnosis of CKD of stages from II to $\mathrm{V}$ at Mansoura University Children Hospital (MUCH) Nephrology Unit from March 2015 to March 2016. There were 34 (56.7\%) males and $26(43.3 \%)$ females with mean age \pm $\mathrm{SD}$ was $11.06 \pm 3.4$. Control group comprised 30 healthy children they were 18 male $(60 \%)$ and 12 (40\%) female with mean age SD \pm of $9.6 \pm 2.3$.

Table (1): Demographic characteristics in the studied groups.

\begin{tabular}{lccc}
\hline Parameters & $\begin{array}{c}\text { Controls } \\
\mathrm{n}=30\end{array}$ & $\begin{array}{c}\text { Renal insufficiency } \\
\mathrm{n}=60\end{array}$ & $\begin{array}{c}p \text { - } \\
\text { value }\end{array}$ \\
\hline Age (year) & $9.6 \pm 2.3 \mathrm{~A}$ & $11.06 \pm 3.4$ & $0.06^{*}$ \\
$\begin{array}{l}\text { Sex: } \\
\quad \text { Male }\end{array}$ & $18(60 \%)$ & $34(56.7 \%)$ & $0.09^{* *}$ \\
$\quad$ Female & $12(40 \%)$ & $26(43.3 \%)$ & \\
\hline
\end{tabular}

Test: Student $t$-test */Chi square **.

There were no statistically significance differences between both studied groups (control and renal insufficiency groups) as regard age and sex $(p$-value <0.05).
Table (2): Etiology of chronic renal insufficiency in studied cases at the beginning of the study.

\begin{tabular}{lll}
\hline Primary diagnosis & CKD n (\%) & ESRD n (\%) \\
\hline Reflux nephropathy & $11(36.7 \%)$ & $8(26.7 \%)$ \\
Renal aplasia/hypo/dysplasia & $6(20 \%)$ & $5(16.7 \%)$ \\
Focal segmental glomerulosclerosis & $4(13 . \%)$ & $3(10 \%)$ \\
Glomerulonephritis & $2(6.7 \%)$ & $3(10 \%)$ \\
Nephrotic syndrome & $2(6.7 \%)$ & $4(13.3 \%)$ \\
Renal tubular disease & $2(6.7 \%)$ & $2(6.7 \%)$ \\
Unkown & $3(10 \%)$ & $5(16.7 \%)$ \\
\hline
\end{tabular}

Table (2) showed etiology of renal insufficiency in studied groups at the beginning of the study. Reflux nephropathy showed higher frequency in CKD (36.7\%) versus ESRD (26.6\%) groups followed by renal anatomical malformation represented by renal aplasia/hypo/dysplasia 6 (20\%). In contrary the least causes of CKD are focal segmental glomerulosclerosis 4 (13.3\%), Glomerulonephritis $2(6.7 \%)$, nephrotic syndrome $2(6.7 \%)$, renal tubuar disease $2(6.7 \%)$ and unknown etiology versus $3(10 \%), 3(10 \%), 4(13.3 \%), 2(6.7 \%)$ and $5(16.7 \%)$ respectively in ESRD.

Table (3): Average levels of GFR of studied groups.

\begin{tabular}{lcclr}
\hline Parameters & $\begin{array}{c}\text { Controls } \\
\mathrm{n}=30\end{array}$ & $\begin{array}{c}\mathrm{CKD} \text { (stages 2-4) } \\
\mathrm{n}=30\end{array}$ & $\begin{array}{c}\mathrm{ESRD} \\
\mathrm{n}=30\end{array}$ & $\begin{array}{c}p- \\
\text { value }\end{array}$ \\
\hline$\cdot \mathrm{GFR}(\mathrm{ml} / \mathrm{min} /$ & $119.9 \pm$ & $48.7 \pm 20.2 \mathrm{ab}$ & $9.06 \pm<0.001$ \\
$\left.1.73 \mathrm{~m}^{2}\right)$ & $18.5 \mathrm{a}$ & & $1.8 \mathrm{ab}$ \\
\hline
\end{tabular}

Similar letters ${ }^{(A B C)}$ in study groups indicate the presence of statistically significant difference ( $p<0.05) . b$ : CKD versus ESRD:

The above table showed that there was significant decrease in GFR in studied groups (CKD and ESRD) compared to control group ( $p$-value $>0.001$ ).

Table (4): Evaluation of biochemical markers among studied groups.

\begin{tabular}{|c|c|c|c|c|}
\hline Parameters & $\begin{array}{c}\text { Controls } \\
n=30 \\
\text { Mean } \pm \mathrm{SD}\end{array}$ & $\begin{array}{c}\text { CKD } \\
n=30 \\
\text { Mean } \pm S D\end{array}$ & $\begin{array}{c}\text { ESRD } \\
n=30 \\
\text { Mean } \pm \text { Sd }\end{array}$ & $\begin{array}{c}p- \\
\text { value }\end{array}$ \\
\hline Albumin & $4.4 \pm 0.37$ & $4.3 \pm 0.28$ & $4.3 \pm 0.27$ & 0.4 \\
\hline $\begin{array}{l}\text { Calcium: } \\
\quad(\text { Mean } \pm \mathrm{SD})\end{array}$ & $9.9 \pm 0.8$ & $9.04 \pm 1.00$ & $8.4 \pm 1.21$ & $<0.001 *$ \\
\hline $\begin{array}{l}\text { Phosphorus: } \\
\quad(\text { Mean } \pm \text { SD) }\end{array}$ & $3.9 \pm 0.5 \mathrm{AB}$ & $4.9 \pm 1.6 \mathrm{~B}$ & $5.3 \pm 2.6 \mathrm{~A}$ & $0.01 *$ \\
\hline $\begin{array}{l}\text { Alkaline } \\
\text { phosphatase: } \\
\text { Median } \\
\text { (Min-max) }\end{array}$ & $\begin{array}{l}162 \\
(120.0-194.0)\end{array}$ & $\begin{array}{l}292 \\
(172.0-623.0)\end{array}$ & $\begin{array}{l}583.5 \\
(114-3200)\end{array}$ & $<0.001 *$ \\
\hline $\begin{array}{l}\text { Parathormone } \\
\text { (PTH): } \\
\text { Median } \\
\text { (Min-max) }\end{array}$ & $\begin{array}{l}60 \\
(35-84)\end{array}$ & $\begin{array}{l}76 \\
(37-170)\end{array}$ & $\begin{array}{l}526 \\
(58-3379)\end{array}$ & $<0.001 *$ \\
\hline
\end{tabular}


Similar letters ${ }^{(A B C)}$ in study groups indicate the presence of statistically significant difference $(p<0.05)$ :

Table (4) showed that there were statistically higher level in serum phosphorus, alkaline phosphatase and PTH in ESRD group compared to other groups ( $p$-value >0.001). There was statistically significant lower level of serum Ca in ESRD group compared to other groups ( $p$-value $>0.05$ ).

There was no statistically significant difference as regards serum albumin level between studied groups $(p$-value $<0.05)$.

Table (5): Evaluation of anthropometric values among studied groups.

\begin{tabular}{lcccc}
\hline Parameters & $\begin{array}{c}\text { Controls } \\
\mathrm{n}=30 \\
\text { Mean } \pm \mathrm{SD}\end{array}$ & $\begin{array}{c}\mathrm{CKD} \\
\mathrm{n}=30 \\
\text { Mean } \pm \mathrm{SD}\end{array}$ & $\begin{array}{c}\text { ESRD } \\
\mathrm{n}=30 \\
\text { Mean } \pm \mathrm{SD}\end{array}$ & $\begin{array}{c}p \text { - } \\
\text { value }\end{array}$ \\
\hline Height SD & $179.5 \pm 8.8$ & $149.5 \pm 8.8$ & $129.4 \pm 7.8$ & $<0.001^{*}$ \\
Waist/hip ratio & $0.8 \pm 0.26$ & $1.4 \pm 1.76$ & $1.2 \pm 0.68$ & 0.08 \\
\hline
\end{tabular}

Table (5) showed statistically significant decrease in height SDS in CKD compared to other groups ( $p$-value $>0.05$ ). However, waist/hip ratio also show increase in CKD \& ESRD compared to control group but of no statistically significant difference ( $p$-value <0.05).

Table (6): Evaluation of bone density parameters by Dual Energy X-Ray Absorptiometry (DXA) among studied groups.

\begin{tabular}{lclcc}
\hline Parameters & $\begin{array}{c}\text { Control } \\
\mathrm{n}=30\end{array}$ & \multicolumn{1}{c}{$\begin{array}{c}\mathrm{CKD} \\
\mathrm{n}=30\end{array}$} & $\begin{array}{c}\text { ESRD } \\
\mathrm{n}=30\end{array}$ & $\begin{array}{c}p \text { - } \\
\text { value }\end{array}$ \\
\hline $\begin{array}{l}\text { Z score L1-L4 } \\
\text { (median) }\end{array}$ & $\begin{array}{l}-0.47 \pm 0.92 \mathrm{c} \\
(-0.40)\end{array}$ & $\begin{array}{l}-1.12 \pm 1.27 \mathrm{bc} \\
(-1.30)\end{array}$ & $\begin{array}{l}-1.5 \pm 1.4 \mathrm{bc} \\
(-1.8)\end{array}$ & $0.003^{*}$ \\
\hline
\end{tabular}

Similar letters ${ }^{(a b c)}$ in study groups indicate the presence of statistically significant difference $(p<0.05)$ :

Table (6) showed statistically significant decrease in Z score L1-L4 in ESRD group compared to other groups ( $p$-value $>0.05$ ).

Table (6) showed there was significant statistically differences in height in ESRD \& CKD compared to control group ( $p$-value $>0.001)$. There were no significant statistically differences between studied groups as regard free fat mass, fat $\%$ and muscle mass ( $p$-value $<0.05$ ).

Table (8) showed non-significant increase in median level of sclerostin that was higher in CKD patients and was highest in those with in ESRD $(p$-value $<0.05)$.
Table (7): Evaluation of body composition values by Bioelectrical Impedance Analysis of (BIA) among studied groups.

\begin{tabular}{|c|c|c|c|c|}
\hline Parameters & $\begin{array}{c}\text { Controls } \\
n=30 \\
\text { Mean } \pm \mathrm{SD}\end{array}$ & $\begin{array}{c}\text { CKD } \\
n=30 \\
\text { Mean } \pm S D\end{array}$ & $\begin{array}{c}\text { ESRD } \\
n=30 \\
\text { Mean } \pm S D\end{array}$ & $\begin{array}{c}p- \\
\text { value }\end{array}$ \\
\hline $\begin{array}{l}\text { Height: } \\
\quad \text { Mean } \pm \mathrm{SD}\end{array}$ & $0.32 \pm 1.6$ & $-2.26 \pm 1.7$ & $-2.18 \pm 2.6$ & $0.001 *$ \\
\hline Total free fat mass & $24.01 \pm 7.8$ & $25.01 \pm 6.6$ & $23.3 \pm 8.1$ & 0.6 \\
\hline FFM right UL & $1.14 \pm 0.9$ & $1.01 \pm 0.3$ & $0.9 \pm 0.4$ & 0.3 \\
\hline FFM left UL & $0.9 \pm 0.3$ & $1.06 \pm 0.3$ & $0.9 \pm 0.4$ & 0.6 \\
\hline FFM right LL & $3.5 \pm 1.7$ & $3.9 \pm 1.3$ & $3.5 \pm 1.5$ & 0.3 \\
\hline FFM left LL & $3.4 \pm 1.5$ & $3.9 \pm 1.2$ & $3.4 \pm 1.5$ & 0.2 \\
\hline FFM trunk median & $15.3 \pm 3.7$ & $14.9 \pm 3.5$ & $14.3 \pm 4.3$ & 0.5 \\
\hline Right UL & $28.8 \pm 8.2$ & $26.9 \pm 5.7$ & $27.4 \pm 5.5$ & 0.5 \\
\hline Left UL & $28.2 \pm 9.06$ & $26.3 \pm 6.2$ & $27.2 \pm 4.4$ & 0.6 \\
\hline Right LL & $25.01 \pm 8.27$ & $22.9 \pm 6.11$ & $25.4 \pm 6.13$ & 0.3 \\
\hline Left LL & $25.2 \pm 8.05$ & $23.3 \pm 6.1$ & $25.3 \pm 5.9$ & 0.4 \\
\hline $\begin{array}{l}\text { Trunk: } \\
\quad \text { Median }\end{array}$ & $\begin{array}{l}13.3 \pm 7.9 \\
(11.7)\end{array}$ & $\begin{array}{l}12.8 \pm 5.33 \\
(12.6)\end{array}$ & $\begin{array}{l}14.6 \pm 7.1 \\
(13.7)\end{array}$ & 0.6 \\
\hline $\begin{array}{l}\text { Right UL: } \\
\text { Median }\end{array}$ & $\begin{array}{l}1 \pm 0.3 \\
1.00\end{array}$ & $\begin{array}{l}0.9 \pm 0.5 \\
0.8\end{array}$ & $\begin{array}{l}1 \pm 0.9 \\
0.9\end{array}$ & 0.5 \\
\hline $\begin{array}{l}\text { Left UL: } \\
\quad \text { Median }\end{array}$ & $\begin{array}{l}1 \pm 0.3 \\
1.1\end{array}$ & $\begin{array}{l}0.9 \pm 0.5 \\
0.8\end{array}$ & $\begin{array}{l}0.9 \pm 0.4 \\
0.9\end{array}$ & 0.6 \\
\hline $\begin{array}{l}\text { Right LL: } \\
\quad \text { Median }\end{array}$ & $\begin{array}{l}3.8 \pm 1.2 \\
3.8\end{array}$ & $\begin{array}{l}3.3 \pm 1.4 \\
3.2\end{array}$ & $\begin{array}{l}3.4 \pm 1.6 \\
3.2\end{array}$ & 0.4 \\
\hline $\begin{array}{l}\text { Left LL: } \\
\quad \text { Median }\end{array}$ & $\begin{array}{l}3.8 \pm 1.2 \\
3.7\end{array}$ & $\begin{array}{l}3.3 \pm 1.4 \\
3.1\end{array}$ & $\begin{array}{l}3.3 \pm 1.5 \\
3.1\end{array}$ & 0.3 \\
\hline $\begin{array}{l}\text { Trunk: } \\
\quad \text { Median }\end{array}$ & $\begin{array}{l}14.4 \pm 3.5 \\
14.5\end{array}$ & $\begin{array}{l}13.8 \pm 4.1 \\
12.7\end{array}$ & $\begin{array}{l}14.7 \pm 3.6 \\
14.4\end{array}$ & 0.6 \\
\hline
\end{tabular}

Table (8): Comparison of sclerostin level between studied groups.

\begin{tabular}{lclll}
\hline Parameters & $\begin{array}{c}\text { Sclerostin in } \\
\text { control } \\
(\mathrm{n}=30)\end{array}$ & $\begin{array}{c}\text { Sclerostin } \\
\text { in CKD } \\
(\mathrm{n}=30)\end{array}$ & $\begin{array}{c}\text { Sclerostin } \\
\text { in ESRD } \\
(\mathrm{n}=30)\end{array}$ & $\begin{array}{c}p^{-} \\
\text {value }\end{array}$ \\
\hline Median & 2012.5 & 3151 & 4348 & 0.07 \\
Min-max & $365-7010$ & $448-6806$ & $420-7247$ & \\
\hline
\end{tabular}

Table (9): Correlation between sclerostin and anthropometric values among control and renal insufficiency groups.

\begin{tabular}{lcc}
\hline Parameters & $\begin{array}{c}\text { Sclerostin in control } \\
(\mathrm{n}=30) \\
r(p)\end{array}$ & $\begin{array}{c}\text { Sclerostin in renal } \\
\text { insufficiency }(\mathrm{n}=60) \\
r(p)\end{array}$ \\
\hline Height SD & $-0.13(0.4)$ & $-0.09(0.4)$ \\
Waist/hip ratio & $0.15(0.43)$ & $0.12(0.33)$ \\
\hline
\end{tabular}

$r$ : Pearson's rank correlation coefficient.

Table (9) showed non-significant correlation between level of sclerostin as regard height and waist/hip ratio in studied groups ( $p$-value $<0.05$ ).

Table (10) showed non-significant positive correlation with serum sclerostin level and PTH and alkaline phosphatase while negative with calcium and phosphorus in renal affection groups with no statistical significance ( $p$-value $<0.05$ ). 
Table (10): Correlation between sclerostin level and biochemical parameters of study groups.

\begin{tabular}{lcc}
\hline Parameters & $\begin{array}{c}\text { Sclerostin in control } \\
(\mathrm{n}=30) \\
r(p)\end{array}$ & $\begin{array}{c}\text { Sclerostin in renal } \\
\text { affection gb }(\mathrm{n}=60) \\
r(p)\end{array}$ \\
\hline Albumin & $0.02(0.9)$ & $-0.15(0.4)$ \\
Calcium & $0.17(0.3)$ & $-0.03(0.3)$ \\
Phosphorus & $0.16(0.4)$ & $-0.26(0.1)$ \\
Alkaline phosphatase & $-0.09(0.6)$ & $0.22(0.4)$ \\
Parathormone hormone & $-0.13(0.4)$ & $0.15(0.2)$ \\
\hline
\end{tabular}

Table (11): Correlation between sclerostin level and anthropometric, BIA, BCM and DXA values of study groups and control group.

\begin{tabular}{lcc}
\hline & $\begin{array}{c}\text { Sclerostin in control } \\
(\mathrm{n}=30) \\
r(p)\end{array}$ & $\begin{array}{c}\text { Sclerostin in renal } \\
\text { affection gb }(\mathrm{n}=60) \\
r(p)\end{array}$ \\
\hline Height SD & $0.13(0.4)$ & $-0.09(0.4)$ \\
Fat mass $(\%):$ & & \\
$\quad$ Right UL & $0.04(0.07)$ & $-0.11(0.3)$ \\
Left UL & $0.1(0.5)$ & $-0.10(0.4)$ \\
Right LL & $0.07(0.7)$ & $-0.21(0.09)$ \\
Left LL & $0.06(0.7)$ & $-0.12(0.3)$ \\
Trunk & $0.09(0.6)$ & $-0.12(0.3)$ \\
Free fat mass: & & \\
Right UL & $0.95(.61)$ & $-0.05(0.7)$ \\
Left UL & $0.03(.85)$ & $-0.01(0.9)$ \\
Right LL & $0.08(.66)$ & $-0.01(0.9)$ \\
Left LL & $0.12(.52)$ & $-0.04(0.7)$ \\
Trunk & $0.19(.30)$ & $-0.02(0.8)$ \\
Muscle mass $($ Kg $):$ & & \\
Right UL & $0.06(0.7)$ & $0.02(0.8)$ \\
Left UL & $0.05(0.7)$ & $-0.03(0.8)$ \\
Right LL & $0.11(0.5)$ & $-0.02(0.8)$ \\
Left LL & $0.16(0.3)$ & $-0.05(0.6)$ \\
Trunk & $0.19(0.3)$ & $-0.03(0.7)$ \\
Z score L1-L4 & $-0.12(0.5)$ & $-0.13(0.3)$ \\
\hline
\end{tabular}

Table (11) showed negative correlation with no statistical significance between serum level of sclerostin and anthropometric, BIA BCM, and DXA as regard (height, fat mass \%, muscle mass $(\mathrm{Kg})$ and score L1-L4) among different parts of the body ( $p$-value $<0.05)$.

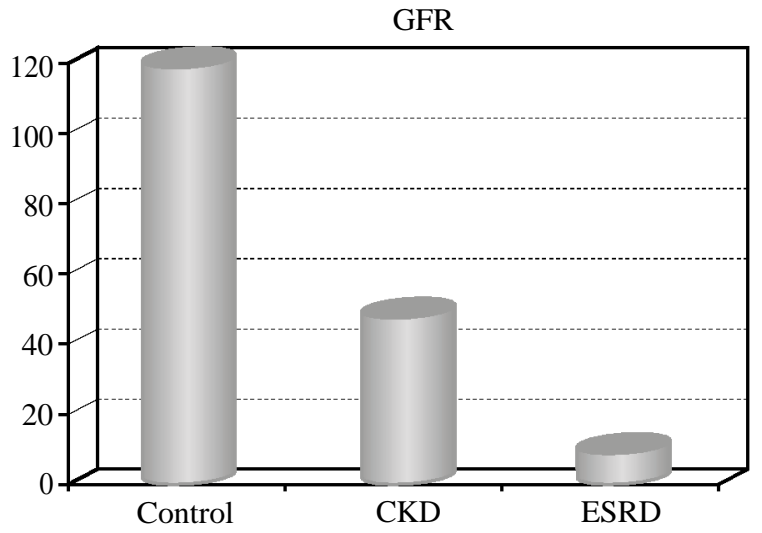

Fig. (2): Comparison of GFR level between studied groups.

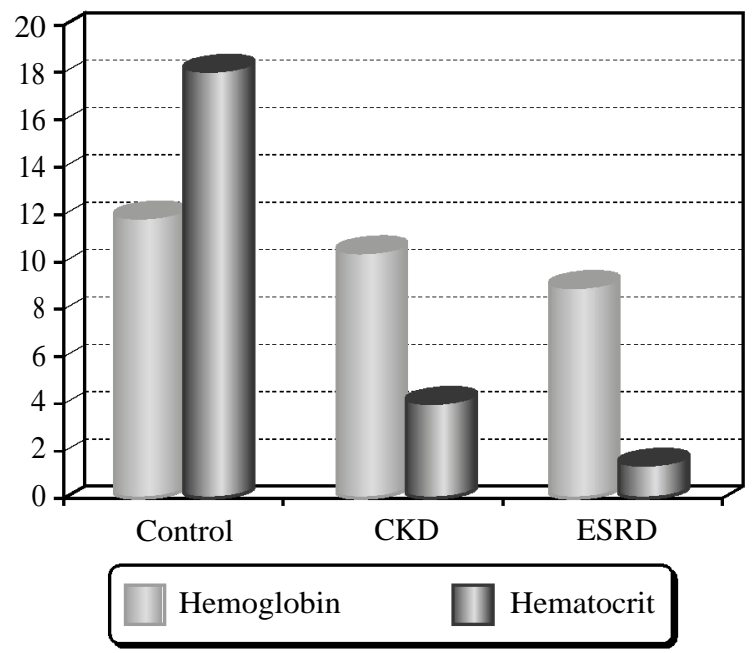

Fig. (3): Means of hemoglobin and hematocrit among the three studied groups.

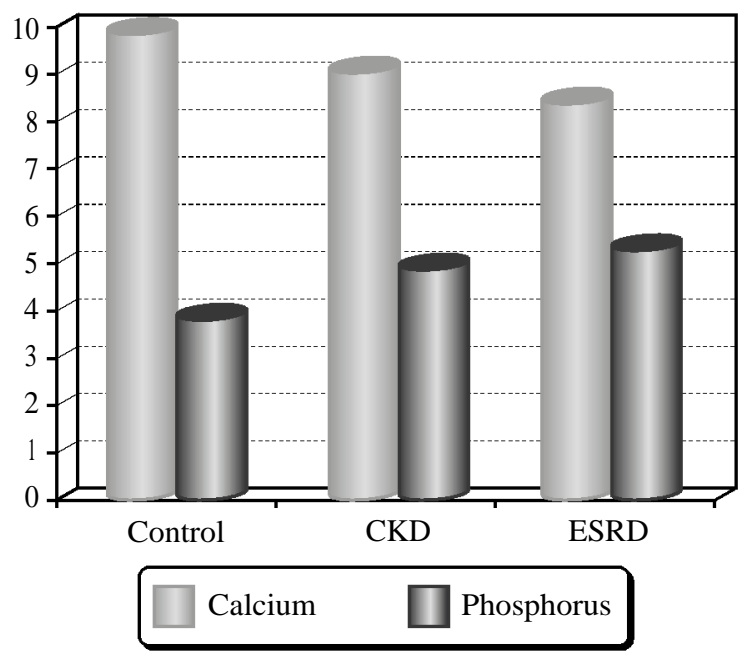

Fig. (4): Means of calcium and phosphorus among the three studied groups.

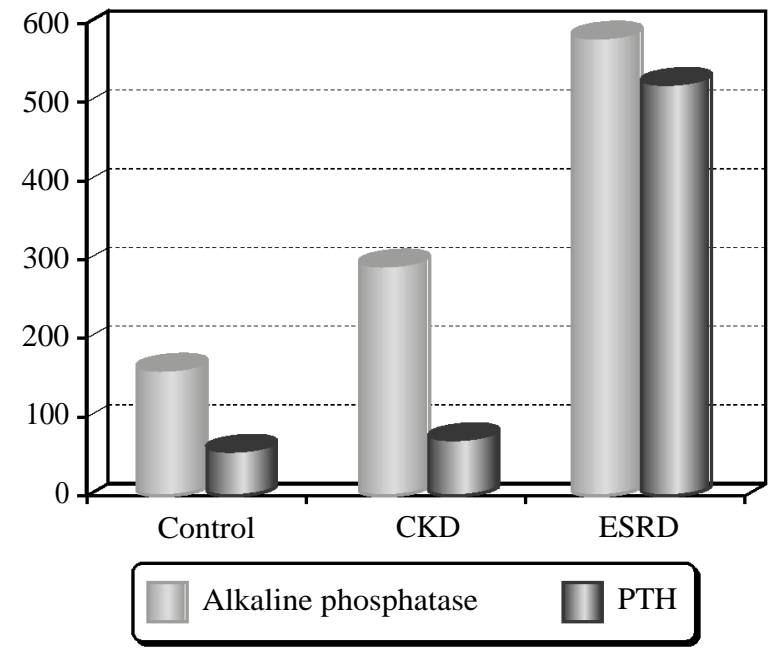

Fig. (5): Medians of alkaline phosphatase and PTH among the three studied groups. 


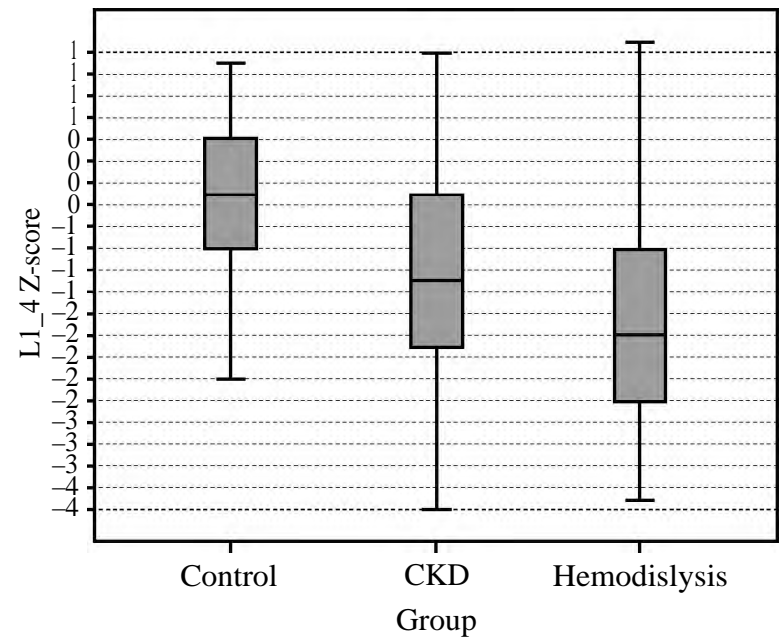

Fig. (6): Boxplot for comparison of median L 1-L4 Z-score values among studied groups.

\section{Discussion}

Chronic Kidney Disease (CKD) is a major health problem and report increased risks of mortality and morbidities, which estimate $10-15 \%$ of the general population Worldwide [16]

As kidney function worsens there is a progressive alteration of mineral homeostasis with a disruption of normal serum and tissue concentrations of phosphorus and calcium and changes in circulating levels of hormones. Chronic Kidney DiseaseMetabolic Bone Disorder (CKD-MBD) is an exceedingly complication of kidney diseases defined as an abnormalities in mineral and hormone metabolism associated with increased fracture rates and pathologic changes resulting from declining bone health and soft tissue calcification (kidney disease: Improving Global Outcomes [7].

Bone Turnover Marker (BTMs) in blood and urine will be a new area in reflecting bone activity and may be useful in the diagnosis and management of different metabolic diseases affecting bones. Newer markers are currently being investigated to explain their role in bone metabolism disease and may be useful in the future in clinical diagnosis and management of metabolic bone disorders. Also for monitoring therapy which will offer useful additional data in skeletal diseases that are typically characterised by increased bone remodeling like CKD but further data are required to amalgamate their clinical use [7]

Sclerostin is a novel chemical marker for assessing bone metabolic disorder and vascular disease, it was recognized as mutations in gene named as SOST gene, that encode sclerostin as the cause of sclerosteosis in 2001. In healthy children, scle- rostin levels are higher in boys decline during puberty and are positively correlated with the cortical porosity index [17].

Sclerostin act as an inhibitor of the Wnt coreceptor low density lipoprotein receptor-related protein indicated that serum sclerostin levels may reflect reduced bone metabolism and may be useful as a marker for low-turnover bone disease and renal osteodystrophy in End Stage Renal Disease (ESRD) patients [18] .

This study was done on 90 children. 60 children were having chronic renal disease, 34 males $(57.7 \%), 26$ females (42.2\%) and control group which consisted of 30 healthy children.

It was conducted in Mansoura University Children Hospital from 2015 to 2016.

According to our results sclerostin level was markedly increased with advancement of CKD stages reaching levels higher in ESRD, this is in agreement with Cejka [11]; Delanaye [19]. This is possibly due to: A) Its molecular mass of 22DKD cleared by kidney thus decreasing GFR resulting in its accumulation and reduction of bio-degradation despite increases in the fraction excreted into urine with the progression of CKD. B) Accumulation of sclerostin in circulation a stronger inhibition of osteoblasts that lower level of bone formation through inhibition of (canonical) Wnt- 0 -catenin pathway thus, lower bones turnover with increased bone resorption [20]. C) In uremic patient skeleton is partially resistant to action of PTH due to down regulation of its receptors and accumulation of antagonistic PTH fragments thus the reduced effect of PTH on bone will decrease inhibition of SOST which will stimulate expression of sclerostin [20].

According to our results we found positive correlations as regard serum levels of sclerostin PTH and alkaline phosphatase in renal insufficiency groups. This in agreement with [20]. Possible explanation may be PTH resistance or presence of relationship between sclerostin, PTH and phosphate. Sclerostin may be contributing to $\mathrm{PTH}$ resistance in CKD with other factors such as calcitriol deficiency. Other studies showed that serum phosphate was independently associated with sclerostin level in patients with CKD as phosphate diet stimulated bone sclerostin expression independently of PTH in a model of CKD-a dynamic bone disease (ABD) [18] .

In disagreement with our results, [21,22] showed that sclerostin and PTH levels were not related with each other's in CKD patients, it can be ex- 
plained by lack of measurement of iPTH (intact PTH) level in our CKD population which was relatively low, different methodological studies regarding the type of CKD population and of sclerostin assays and possibly the hypothesis of PTHindependent mechanisms for sclerostin regulation and skeletal resistance to the action of PTH can explain this affection [23].

According to our results we found negative correlations as regard serum sclerostin and phosphate levels this in agreement with Mathew et al., 2007. Who stated that controlling serum phosphate by using phosphate binders, there by reverse CKDproduce osteopenia leading to increased osteoblast surfaces of the lower end tibia and neck of femur. Another explanation has been postulated by [21] [19] which is the presence of direct connection pathway between sclerostin and phosphate, this pathway composed of phosphate or any phosphate combining molecule receptors on the surface of osteocytes that encourages the release of sclerostin [19].

According to our results CKD and ESRD patients had higher level of serum phosphorus, serum PTH and alkaline phosphatase while they show significant lower level of serum calcium compared to control groups which in agreement with Kidney Disease Improving Global Outcome guideline (KDIGO) and Chronic Kidney Disease-Bone Mineral Density (CKD-BMD) [7].

Hyperphosphatemia and hyperparthyrodism can be explained by three main factors which are decrease in calcitriol, decrease in calcium and inhibition of proximal tubular phosphate whereas the direct effects of up regulation of PTH, FGF23 (fibroblast growth factor 23) appear to be essentially limited to the control of PTH synthesis and secretion. As CKD progresses, renal phosphate excretory capacity becomes exhausted and hyperphosphatemia ensues leading to (A) Increase serum PTH leading to renal osteodystrophy and (B) Increase Fibroblast growth factor 23 which is potent novel phosphaturic factor that can inhibit both renal phosphate reabsorption and 25 hydroxyvitamine D- $1 \alpha$ hydroxylase activities in proximal tubule. Secondary hyperparathyroidism develops in CKD and ESRD patients due to hyperphosphatemia, hypocalcemia, $1,25(\mathrm{OH}) 2$ vitamin $\mathrm{D}$ deficiency, skeletal resistance to vitamin $\mathrm{D}$ and reduced expression of calcium sensing receptor, hence bone disorder in CKD-MBD varies widely from a high bone turnover state (osteitis fibrosa cystica) due to excessive PTH elevation to a low turnover and adynamic state due often to PTH over-suppression [20].

In agreement with our results Manal Abd Elsalam [20] found inverse correlations between serum sclerostin and serum calcium levels, possibly due to metabolic dysregulation may accompany CKD affected by the kidney disease itself or due to dialysis treatment. CKD may cause insufficiency of some essential elements that may be caused by increased losses throughout dialysis sessions, malnutrition, decreased intestinal absorption such as impaired calcium absorption and duration of dialysis also may have a role.

As regarding hypocalcemia in CKD patients, this may be attributed to impaired kidney function that results in limited capacity to produce $1,25(\mathrm{OH})$ 2D3 out of 25(OH)D2 due to different amount of $1 \alpha$-hydroxylase resulting in decreased vitamin D concentrations in addition to suboptimal native vitamin D supplementation and/or elevated FGF23 [26].

Regarding elevated level of Alkaline Phosphatase (ALP) can be due to increase ALP production by osteoblast that it is concentrated in the bone, liver, placenta, leukocytes and kidneys. ALP can also produced by osteoblasts in bone tissue in response to decreased calcium levels and plays an important role in bone mineralization by hydrolyzing pyrophosphate and is used to monitor the metabolic bone disease associated with renal insufficiency. Renal osteodystrophy arises as a consequence of bone remodeling dysregulation due to elevated PTH level that stimulate bone demineralization and lead to high turnover a condition characterised by accelerated rates of bone absorption and resorption with concurrent production of alkaline phosphatase from osteoblast cells contributing to its high levels in plasma as the renal function or GFR decline [20].

Our results showed inverse correlations between serum sclerostin, body composition and Z-score L1-L4, this in agreement with Manal Abd Elsalam, 2018. Probable elucidation that PTH plays a central role in CKD patients for maintenance of calcium homeostasis as PTH persistent chronic elevation increase osteoclast formation in addition to low calcium level, low circulating vitamin D3 concentrations and hyperphosphatemia all leading causes for progress to secondary hyperparathyroidism which has been the primary targeting therapy in CKD patients. As CKD progresses, needs higher PTH levels in order to maintain normal rates of bone formation leading to development of skeletal 
resistance to the actions of PTH. Pathogenesis of these resistances is not fully understood but may be due to accumulation of naturally active PTH fragments plus down regulation of the PTH receptors [27]. Another explanation postulated by Malluche [28] these findings hypothesis that sclerostin would be expected a negative regulator of bone formation, higher serum sclerostin levels promote low bone turnover which leads to loss of bone mass over time.

Modder [29] found that serum sclerostin positively associated with lumbar BMD, possible explanation that serum level of sclerostin which produced by osteocytes reflect osteocyte number. Higher bone mass result in more osteocyte and therefore higher sclerostin level. On other hand sclerostin level were reported to increase with age irrespective of bone mass and associated with bone mass only on older individuals but not in subject under age of 40 years [29]. Other postulated explanation that high sclerostin level lead to decrease osteoclast activity and bone resorption resulting in down regulation of B-catenin a protein which is necessary for PTH mediated osteoclast activation via OPG/RANKL RANK system [30].

Regarding to our results there is significant decrease in bone mineral density in ESRD compared to other groups using DEXA Z score L 1-L4 which in agreement with [30], can be explained by Renal osteodystrophy that is one of the major complications in patients with End Stage Renal Disease (ESRD) receiving long term hemodialysis with increasing risks of fractures. Osteitis fibrosa cystica the most commonly encountered bone abnormality in renal osteodystrophy as secondary hyperparathyroidism characterized by persistent elevated parathyroid hormone (PTH) leading to marked parathyroid hyperplasia is the leading cause of osteitis fibrosa cystica appeared as an increased bone turnover, associated with reduced bone density, osteopenia and osteoporosis. At the early stage, improvement of renal osteodystrophy would be an expected by suppressing PTH with phosphate binders, calcitriol analogs and calcimimetics, at the late stage there is progressive reducing in expression of calcium sensing receptors and vitamin $D$ receptors result in resistance to medical therapy. The impact of total parathyroidectomy without auto transplantation on bone health in secondary hyperparathyroidism remains uncertain [20].

Our results reported there was no evident difference in measurement between studied groups in different body compositions values as regard (free fat mass, fat $\%$ and muscle mass) by Bioelec- trical Impedance Analysis of (BIA) which in agreement with [31].

In disagreement with our results [20], reported significant associations between loss of lean mass, kidney disease severity and physical activity in individuals with CKD resulting in losses in skeletal muscle mass, possibly due to maintenance of lean mass is dependent on: A) Patients with CKD pre dialysis were shown to experience reductions in strength, balance and gait speed, suggesting compromised physical function early in the disease process, where as physical function of patients with CKD not treated with dialysis is shown to be a stronger predictor of 3-year mortality, upon the initiation of dialysis resulting also in rapid and sustained declines in physical function [20], B) The relationship between protein synthesis and protein degradation, in CKD, this relationship is altered which favoring protein degradation, accelerating the rate of skeletal muscle mass lost in addition to other potential mechanisms include metabolic acidosis, insulin/insulin-like growth factor 1 (IGF1), inflammation and appetite regulation expression (Wang and Mitch, 2014). C) Muscle specific miro RNAs could novel targets for interventions to prevent, treat muscle protein loss and protein malnutrition, in CKD muscle the microRNA expression pattern is altered and it is level depressed, increasing YinYang 1 protein that negatively regulating myogenesis [32].

In this study we found that the majority of our cases had urological abnormalities $(31.7 \%)$ including reflux nephropathy, anatomical kidney malformation was the second common etiology (20\%) other causes include glomerular diseases as (glomerulonephritis, nephrotic syndrome and renal tubular disease). Three (10\%) cases has unkown etiolology. Revising the literature revealed that the etiology of CKD differ according to age distribution of studied cases, socioeconomic status and availability of investigation tools.these was in agreement with [33]

Safouh [33] found that CKD causes in Egyptian children followed-up at the pediatric nephrology units (outpatient clinics and dialysis units) of 11 universities over a period of two years were obstructive uropathy (21.7\%), primary glomerulonephritis $(15.3 \%)$, reflux/urinary tract infection (14.6\%), aplasia or hypoplasia (9.8\%), familial/ metabolic diseases $(6.8 \%)$ and unknown causes which represent $20.6 \%$ of the cases.

According to our results as regard anthropometric measures, we found that CKD patients' suffering 
from delay or impaired growth which is intensely associated with arrest of linear growth compared with control group, height of $66.6 \%$ of the patients was below the $5 \mathrm{rd}$ percentile for age and sex. This is in agreement with [34]. The possible explanation may be due to an raised level of insulin like growth (I-LGF) factor and increased hepatic synthesis, as the bioavailability of insulin-like growth factor decrease, this leads to a decrease in the expression of growth hormone hepatic receptor and decreased production of insulin-like growth factor, or may be represented as complications of childhood CKD due to phase change of growth hormone that is $\mathrm{GH}$ dependant and resistance to its action.

According to our results we found that assessing nutritional status using serum albumin level we found it within normal ranges. This is in agreement with [7], possible explanation that serum albumin is limited as a marker of malnutrition in the setting of CKD that it may be unaffected by acute changes in nutritional status because of its long half-life. Furthermore, serum albumin is low in both setting of systemic inflammation and volume-overload states [7]

According to our results regarding laboratory findings haemglobin and haematocrite were significantly lower in CKD and ESRD than in control group and this in agreement with [7].

Accoding to its type, such as malnutrition, inceased blood loss via GIT, decreasd erythropoietin production from the kidney, BM depression 2ry to chronic inflammatory processes and malabsorption [7].

Anemia in CKD can be explained by different mechanisms, major cause is a relative deficiency in erythropoietin (EPO) production, due to decrease in the synthesis of erythropoietin hormone which is produced from kidneys in response to many factors such as hypoxia and active vitamin D3 this hormone responsible of erythropoiesis in the bone marrow and regulating bone calcium and phosphorus, in addition to malnutrition, blood loss via GIT, $\mathrm{BM}$ depression 2ry to chronic inflammatory processes and malabsorption [36]

\section{References}

1- LEVEY A.S., ECKARDT K.U., TSUKAMOTO Y., et al.: Definition and classification of chronic kidney disease: A position statement from Kidney Disease: Improving Global Outcomes (KDIGO). Kidney Int., 67 (6): 2089100, 2005

2- MOE S., DRÜEKE T., CUNNINGHAM J., et al.: "Definition, evaluation, and classification of renal osteodystrophy: A position statement from Kidney Disease: improving Global Outcomes (KDIGO),"Kidney International, 69 (11): 1945-53, 2006.

3- JOY M.S., KARAGIANNIS P.C. and PEYERL F.W.: Outcomes of secondary hyperparathyroidism in chronic kidney disease and the direct costs of treatment. J. Manag. Care Pharm., 13: 397-411, 2007.

4- GARDHAM C., STEVENS P.E., DELANEY M.P., et al.: Variability of parathyroid hormone and other markers of bone mineral metabolism in patients receiving hemodialysis. Clin. J. Am. Soc. Nephrol., 5: 1261-7, 2010.

5- CAVALIER E., DELANAYE P. and MORANNE O.: Variability of new bone mineral metabolism markers in patients treated with maintenance hemodialysis: Implications for clinical decision-making. Am. J. Kidney Dis. 61: 847-8, 2013.

6- LU Y. and FENG J.Q.: FGF23 in Skeletal Modeling and Remodeling. Curr. Osteoporos. Rep., 9: 103-8, 2011.

7- Kidney Disease: Improving Global Outcomes (KDIGO) CKD-MBD Work Group: Clinical practice guideline for the diagnosis, evaluation, prevention and treatment of Chronic Kidney Disease-Mineral and Bone Disorder (CKD-MBD). Kidney Int. Suppl., 76 (Suppl 113): S1S130, 2009.

8- DRÜEKE T.B. and LAFAGE-PROUST M.H.: Sclerostin: Just One More Player in Renal Bone Disease? Clin. J. Am. Soc. Nephrol., 6: 700-3, 2011.

9- GALLI C., PASSERI G. and MACALUSO G.M.: Osteocytes and WNT: The mechanical control of bone formation. J. Dent. Res., 89: 331-43, 2011.

10- SZULC P., BERTHOLON C., BOREL O., et al.: Lower fracture risk in older men with higher sclerostin concentration-a prospective analysis from the MINOS study. $\mathbf{J}$. Bone Miner. Res., 28: 855-64, 2013.

11- CEJKA D., MARCULESCU R., KOZAKOWSKI N., et al.: Renal elimination of sclerostin increases with declining kidney function. J. Clin. Endocrinol. Metab., 99: 248-55, 2014.

12- SCHWARTZ G.J., HAYCOCK G.B., EDELMANN C.M., Jr., et al.: A simple estimate of glomerular filtration rate in children derived from body length and plasma creatinine. Pediatrics, 58: 259-63, 1976.

13- EL-ZINY M.A., AL-TONBARY Y.A., SALAMA O.S., et al.: Low turnover bone disease in Egyptian children with acute leukemia. Hematology, 10 (4): 327-33, 2005.

14- Y1LMAZ F., DEMIREL G. and KUMSAR A.: Cay, obezite ve kadın. Journal of Contemporary Medicine, 6 (2): 137 46, 2016.

15- GILSANZ V. and RATIB O.: Hand Bone Age: A Digital Atlas of Skeletal Maturity, 2011.

16- LEVIN A., HEMMELGARN B., CULLETON B., et al.: Guidelines for the management of chronic kidney disease. CMAJ, 179 (11): 1154-62, 2008

17- ROUDIER M., LI X., NIU Q.T., et al.: Sclerostin is expressed in articular cartilage but loss or inhibition does not affect cartilage remodeling during aging or following mechanical injury. Arthritis Rheum., 65 (3): 721-31, 2013.

18- PELLETIER S., CONFAVREUX C.B., HAESEBAERT J., et al.: Serum sclerostin: The missing link in the bone- 
vessel cross talk in hemodialysis patients? Osteoporos Int., 26: 2165-74, 2015.

19- DELANAYE P., KRZESINSKI J.M., WARLING X., et al.: Clinical and biological determinants of sclerostin plasma concentration in hemodialysis patients. Nephron. Clin. Pract., 128: 127-34, 2014.

20- MANAL ABD ELSALAM: Evaluation of sclerostin serum level and bone density status in children on regular haemodialysis. J. Nephrol. Volume (8), 2018.

21- FERREIRA J., FERRARI G.O., NEVES K.R., et al.: Effects of dietary phosphate on a dynamic bone disease in rats with chronic kidney disease-role of sclerostin? PLoS One, 8 (11): e79721, 2013.

22- YAMADA S., TSURUYA K., TOKUMOTO M., et al.: Factors associated with serum soluble inhibitors of Wntbeta-catenin signaling (sclerostin and dickkopf-1) in patients undergoing peritoneal dialysis. Nephrology, 20: 639-45, 2015

23- DRECHSLER C., EVENEPOEL P., VERVLOET M.G., et al.: High levels of circulating sclerostin is associated with better cardiovascular survival in incident dialysis patients: Results from the NECOSAD study. Nephrol. Dial. Transplant., 30 (2): 288-93, 2015.

24- MATHEW S., LUND R.J., STREBECK F., et al.: Reversal of the adynamic bone disorder and decreased vascular calcification in chronic kidney disease by sevelamer carbonate therapy. J. Am. Soc. Nephrol., 18: 122-30, 2007.

25- DELANAYE P., KRZESINSKI J.M., WARLING X., et al.: Clinical and biological determinants of sclerostin plasma concentration in hemodialysis patients. Nephron. Clin. Pract., 128: 127-34, 2014.

26- ISAKOVA T., WAHL P., VARGAS G.S., et al.: "Fibroblast growth factor 23 is elevated before parathyroid hormone and phosphate in chronic kidney disease," Kidney International, Vol. 79, No. 12, pp. 1370-8, 2011.
27- WESSELING-PERRY K., HARKINS G.C., WANG H., et al.: The calcemic response to continuous PTH (1-34) infusion in end-stage kidney disease varies according to bone turnover. A potential role for PTH (7-84) J. Clin. Endocrinal. Metal., 95: 2772-80, 2010.

28- MALLUCHE H.H., DAVENPORT D.L., CANTOR T., et al.: Bone mineral density and serum biochemical predictors of bone loss in patients with CKD on dialysis. Clin. J. Am. Soc. Nephrol., 9 (7): 1254-62, 2014.

29- MÖDDER U., HOEY K.A., AMIN S., et al.: Relation of age, gender, and bone mass to circulating sclerostin levels in women and men. J. Bone Miner. Res., 26: 373-9, 2011.

30- ROMERO G., SNEDDON W.B., YANG Y., et al.: Parathyroid Hormone Receptor Directly Interacts with Dishevelled to Regulate $\beta$-Catenin Signaling and Osteoclastogenesis. J. Biol. Chem., 285 (19): 14756-63, 2010.

31- PAIK SEONG LIM, CHANG HSU CHEN, FANSAN ZHU, et al.: Validating Body Fat Assessment by Bioelectric Impedance Spectroscopy in Taiwanese Hemodialysis Patients; Volume 27, Issue (1): 37-44, 2017.

32- WANG X.H. and MITCH W.E.: Mechanisms of muscle wasting in chronic kidney disease. Nat. Rev. Nephrol. 10 (9): 504-16, 2014.

33- SAFOUH H., FADEL F., ESSAM R., et al.: Causes of chronic kidney disease in Egyptian children. Saudi J. Kidney Dis. Transpl., 26 (4): 806-9, 2015.

34- SEIKALY M.G., SALHAB N., GIPSON D., et al.: Stature in children with chronic kidney disease: Analysis of NAPRTCS database. Pediatric. Nephrol., 21 (6): 793-9, 2006.

35- KDIGO CKD Work Group. KDIGO: Clinical practice guideline for the evaluation and management of chronic kidney disease. Kidney Int. Suppl., 2013; 3: 1-150, 2012.

36- BABITT J.L. and LIN H.Y.: Mechanisms of anemia in CKD. J. Am. Soc. Nephrol., 23 pp. 1631-4, 2012. 


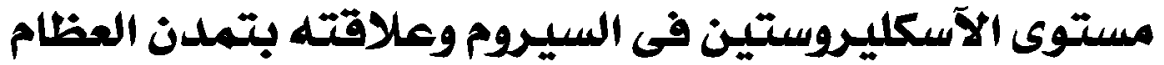

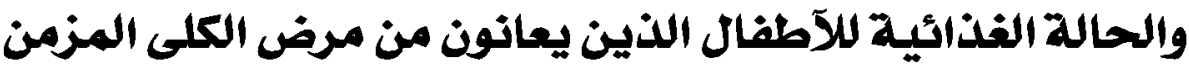

الهدف: قياس مستوى عنصر الإسكليروستين فى الآطفال المصابين بمرض الكلى المزمن فى مراحله المختلفة والعلاقة بينه وبين عوامل الآخرى المؤثرة على تكوين العظام.

يعد مرض الكلى المزمن من مشكلات الصحة العالمية التى كثيراً ما تمر دوف تشخيص آو معالجه، حيث آنها مشكلة تقدمية لا رجعة عنها نتيجة الإنخفاض فى معدل الترشيح الكبييى.

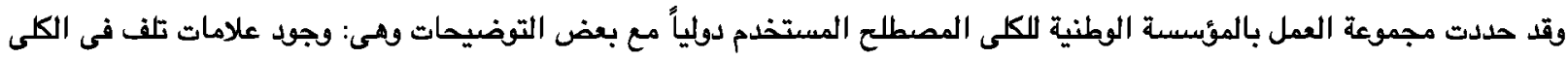

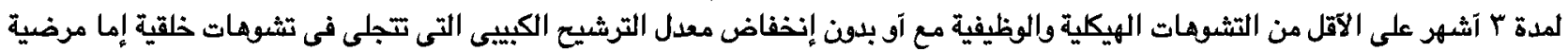

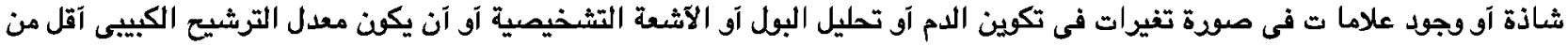

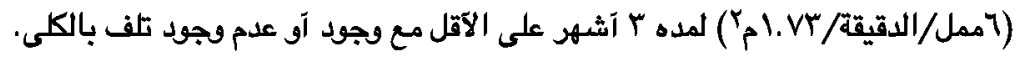

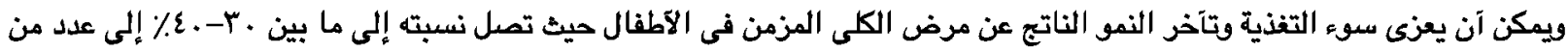

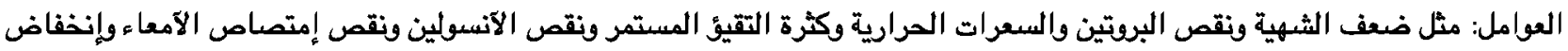

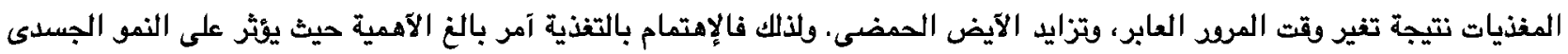
والتمية الإدراكية للآطفال.

مصطلح آمراض الكلى المزمن المرتبطة بإضطرابات العظام "تشمل التشوهات فى العظام والتقاعلات الآيضية المعدنية وترسبات الكالسيوم الثانوية خارج الهيكل العظمى".

يعد من آولى إهتمامـات مؤسسة الكلى تحسين النتائج العالمية لآمراض العظام المعدنية من آسبابها:

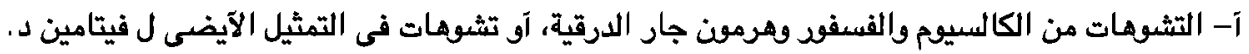

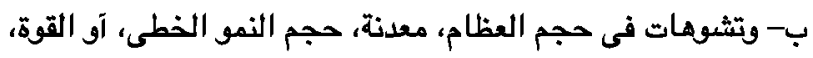

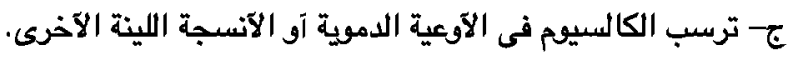

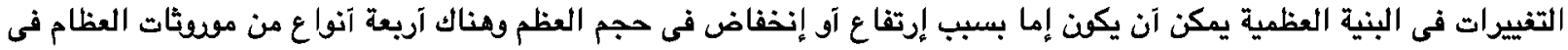

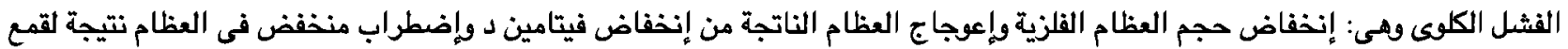

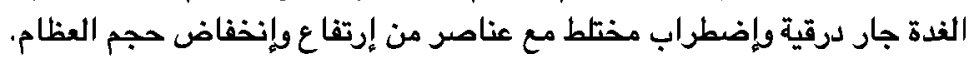
النوع السائد في الفشل الكلوى من إضطراب العظام المعدنية يختلف بين ما قبل الغسيل الكلوى والمرحلة الآخيرة من الفشل الكيل الكلوى.

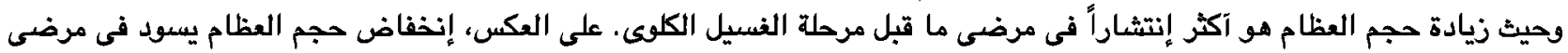

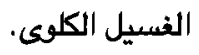

يعد الإسكليوستين منظم سكرى رئيسياً لدودان العظام، حيث يفرز آساساً من الآستيوسيت بناءاً على ردود الفعل السلبية حيث تنظم تشكيل الخلايا السلائف إلى خلايا آوستيويلاستيت.

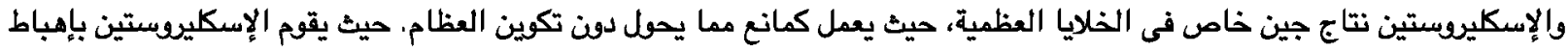

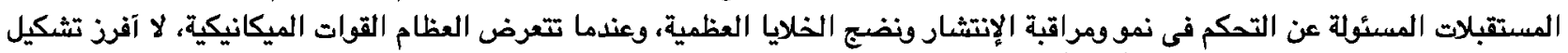

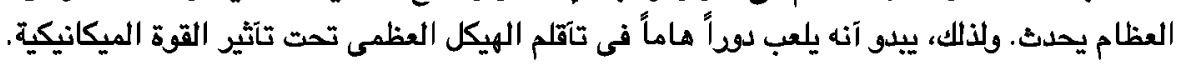

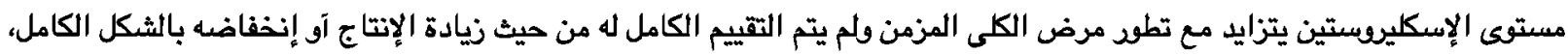

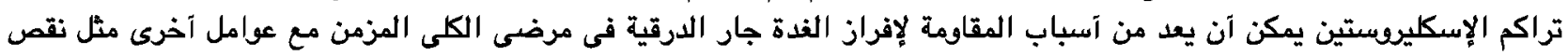

